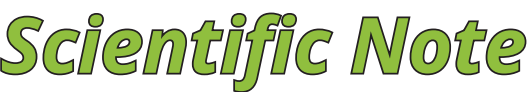

\section{Leaf-cutting ant (Atta laevigata Smith) in an African mahogany plantation in Minas Gerais state, Brazil}

\author{
Rodolfo Molinário de Souza ${ }^{\otimes}$, Andressa Ribeiro ${ }^{\circledR}$ \& Antonio Carlos Ferraz Filho ${ }^{\circledR}$
}

Universidade Federal do Piauí, Curso de Bacharelado em Engenharia Florestal, Bom Jesus, Piauí, Brazil.

\section{EntomoBrasilis 14: e954 (2021)}

\author{
Edited by: \\ William Costa Rodrigues \\ Article History: \\ Received: 20.vii.2021 \\ Accepted: $20 . i x .2021$ \\ Published: 19.x.2021 \\ Corresponding author: \\ Rodolfo Molinário de Souza \\ ७ rodolfosouza@ufpi.edu.br \\ Funding agencies:

Conselho Nacional de
Desenvolvimento Científico
Tecnológico

\begin{abstract}
Khaya grandifoliola C. DC. (Meliaceae), known as African mahogany, is used in the establishment of commercial plantations for high-value timber production. This work aims to report the first occurrence of the genus Atta in a commercial plantation of this species. An ant nest mound with $105 \mathrm{~m}^{2}$ of loose soil and five active ant holes were observed. Leaves cut into crescent shaped sections and pieces of young branches were found near these holes, in addition to trees with the apical part of their crown partially defoliated. The collected specimens were identified as Atta laevigata Smith (Hymenoptera: Formicidae: Attini), locally known as the glass-head leaf-cutting ant.
\end{abstract}

Keywords: Atta; forest pest; glass-head leaf-cutting ant; Khaya grandifoliola; occurrence.

\begin{abstract}
frican mahogany, which belongs to the genus Khaya (Meliaceae), is the common name of tree species with recognized logging potential, most notable of which are the species Khaya anthoteca (Welw.) C. DC., Khaya grandifoliola C. DC., Khaya ivorensis A. Chev. and Khaya senegalensis (Desr.) A. Juss. Khaya grandifoliola, initially identified in Brazil as K. ivorensis, is native to West Africa and its use in commercial plantations in the country is increasing. In addition to its timber market value, one of the reasons for this increase is the possible resistance that African mahogany species have against the attack of the Meliaceae shoot borer (Hypsipyla grandella (Zeller) - Lepidoptera: Pyralidae), which is one of most important forest pests of the native mahogany Swietenia macrophylla King (KLEIN et al. 2016).
\end{abstract}

The expansion of African mahogany plantations in Brazil offers adaptation opportunities for native insects, which can use various parts of the tree as resources for feeding and oviposition, thereby becoming potential pests. An example of this is the occurrence of the Meliaceae shoot borer attacking the fruits, seeds (Lemes et al. 2019) and shoots (ZANETTI et al. 2017) of the trees in African mahogany plantations in Brazil. Other examples of insect species identified as African mahogany pests in Brazilian plantations is the arapuá bee, Trigona spinipes (Fabricius) (Hymenoptera: Apidae) (Moura et al. 2017).

Another group of insects that can compromise the economic viability of commercial African mahogany plantations is the leaf-cutting ants. The costs for the control and maintenance associated with the leaf-cutting ants of the genera Atta and Acromyrmex are already considered in the cash flows by Brazilian producers of African mahogany (RIBEIRo et al. 2018). However, there is still a lack of information on the species of the two genera that occur and cause economic damage in African mahogany plantations, especially for $K$. grandifoliola. (c) The Author(s) 2021. Published by Entomologistas do Brasil

This article is published by Entomologistas do Brasil and licensed under Creative Commons Licence 4.0 (CC-BY)
Given that the success of the control of leaf-cutting ants is dependent on the occurring species, its correct identification is important to support sustainable and integrated pest management in these commercial plantations. Thus, the present work aims to record the occurrence of the leafcutting ant Atta laevigata Smith in a commercial plantation of K. grandifoliola located in Minas Gerais state, Brazil.

The observations were performed in a plantation located in the municipality of São Roque de Minas, in Minas Gerais, Brazil, in July 2019. The area is located within the phytogeographic domain of the Cerrado (Brazilian savannah) surrounding the Serra da Canastra National Park. The climate of the region is subtropical humid with dry winters and temperate summers of the type Cwb, and the soils around the study area are classified as haplic cambisols (dystric).

The ant nest mound was found inside a 9.3-year-old $K$. grandifoliola stand (50 ha), planted with $6 \times 6 \mathrm{~m}$ spacing. At 17:00 h on 10 July 2019, the presence of an ant nest mound with $105 \mathrm{~m}^{2}$ of loose soil $(7 \times 15 \mathrm{~m})$ was observed $\left(46^{\circ} 27^{\prime} 28^{\prime \prime}\right.$ W; $20^{\circ} 06^{\prime 2} 28^{\prime \prime} \mathrm{S}$ and $852 \mathrm{~m}$ altitude, Figure 1A). This nest was located at the base of two trees, which were less than 100 $\mathrm{m}$ from the edge of the stand, and in the presence of sparse ground vegetation comprised of grasses. Five active ant holes located $5 \mathrm{~m}, 6 \mathrm{~m}, 12 \mathrm{~m}, 21 \mathrm{~m}$ and $40 \mathrm{~m}$ away from the area of loose soil were observed (Figures 1B and 1C). The presence of ants was detected in the ant holes found on the loose soil mound, but no foraging activity was observed at that time. However, leaves cut into crescent-shaped sections and pieces of young branches were found near the active holes (Figures 1B and 1C). Dry leaves with the characteristic crescent-shaped cuts were also found near the ant holes on the loose soil mound, evidencing constant, but for some reason interrupted, foraging. Four African mahogany trees (mean total height $=20 \mathrm{~m}$ ) located around the ant nest 
mound were observed with the apical part of the crown partially defoliated (Figure 1D).

Specimens were collected and stored for identification at the Zoology Laboratory of the Universidade Federal do Piauí. Through comparisons, it was revealed that the specimens belonged to the species Atta laevigata Smith (Hymenoptera: Formicidae: Attini). This species is locally known as the glasshead leaf-cutting ant (saúva cabeça de vidro), due to the large and reflected head of its soldiers.

Leaf-cutting ants are the most important group of insects for forest crops in the Neotropical region, as they can cause intense and frequent leaf area reduction at any stage of tree development, thereby reducing growth, and often leading to its death (ZANetTI et al. 2014; JimÉnez et al. 2020). The glass-head leaf-cutting ant can use the leaves of both monocotyledon and dicotyledon species in their foraging activity. In vegetated areas of the Cerrado, A. laevigata selects leaves of different species at least partially based on their on their nitrogen content (SiLVA \& VAsconcelos 2011). Regardless of whether $\mathrm{N}$ concentration is directly involved in plant selection by $A$. laevigata, regular fertilization with this macronutrient, or the $\mathrm{C} / \mathrm{N}$ ratio of the mahogany leaves itself, may explain the selection of $K$. grandifoliola by ants.

The presence of dried and cut leaves near the ant holes (Figure 1B) may be explained by the fact that they were left to dry before being carried inside the ant nest. VASCONCELOS \& CherRetT (1996) observed that A. laevigata worker ants left freshly cut leaves on the soil until the next day of foraging. The authors also observed a preference for tree leaves under water stress, possible changes in nutrient and water content made these leaves more attractive to ants.

The foraging activity of $A$. laevigata worker ants occurs in two stages. The larger ants climb the trees and cut the petiole of the leaves, which fall on the ground and are cut into smaller sections by the worker ants (VAsConcelos \& CheRretT 1996). This may explain the presence of thin cut branches near one of the ant holes (Figure 1C). The foraging activity of adult ant nests, such as the one described here, can remove considerable amounts of leaf biomass from forests.

Leaf-cutting ants of the genus Atta can build nests with an outer layer of loose soil and numerous ant holes. Adult nests of $A$. laevigata can reach depths of seven meters into the ground, with most of the fungal chambers distributed below the loose soil mound (Moreira et al. 2004). These authors suggest that the nests of glass-head leaf-cutting ants may be the deepest, with the largest number of chambers within the Atta genus. In the study area, the active ant holes were located 5-40 m from the loose soil mound. The distribution of ant holes around the loose soil mound expands the foraging areas of the workers and, according to BeATTIE \& Hughes (2003), these ant holes can reach distances of up to $100 \mathrm{~m}$.

The A. laevigata nest was found within the area of occurrence of this species, as defined by Solomon et al. (2008). Other records of the occurrence of this species in the state of Minas Gerais can be found in Magistrall \& Anjos (2011) and Silva \& VASCONCELOS (2011). This is the first record of $A$. laevigata in the municipality of São Roque de Minas. This is also the first record of the foraging activity of $A$. laevigata in African mahogany plantations ( . grandifoliola) in Brazil.

The presence of leaf-cutting ants in forestry plantations causes an undesirable reduction in wood yield and can lead to economic losses higher than the cost of control (JimÉnEz et al. 2020). For example, a single incidence of defoliation by leaf-cutting ants reduced the total wood volume by $37.9 \%$ and three incidences of defoliation reduced the total volume by $79.7 \%$ in eucalyptus plantations (MATRANGolo et al. 2010). Each unitary increment in the area of the Atta spp. nests per hectare reduced the wood production of the eucalyptus forest between $0.04 \mathrm{~m}^{3} \cdot \mathrm{ha}^{-1}$ and $0.13 \mathrm{~m}^{3} \cdot \mathrm{ha}^{-1}$, resulting in a level of economic damage for leaf-cutting ants between 13.4 and $39.2 \mathrm{~m}^{2}$.ha-1 (SouzA et al. 2011). Thus, we recommend that research be carried out in African mahogany plantations to define the economic damage caused by leaf-cutting ants, such as, but not limited to, A. laevigata. It would also be useful to define the sampling parameters within these plantations to accurately estimate infestation levels.
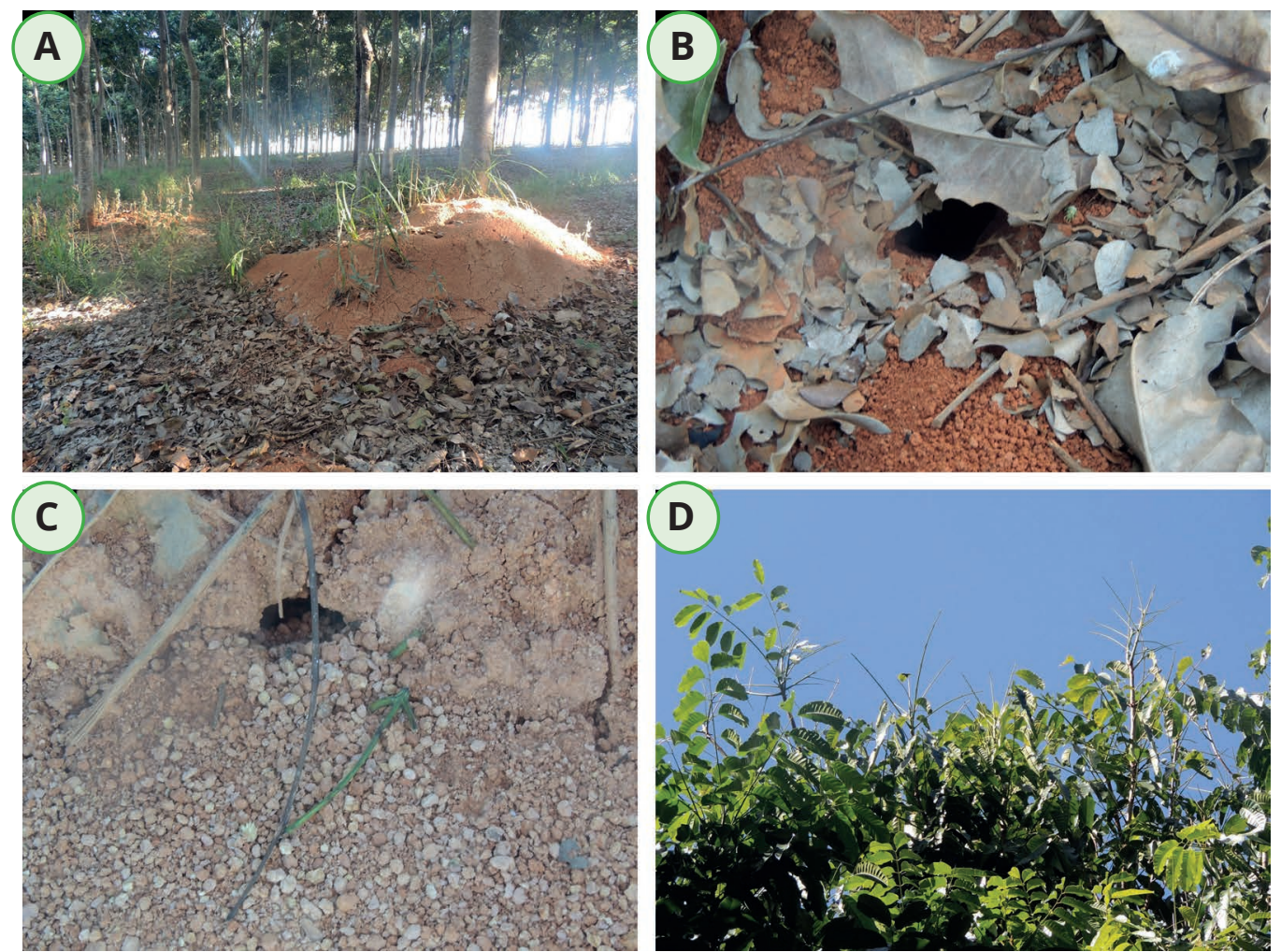

Figure 1. Details of the ant nest mound (A). Ant holes surrounded by dry leaves cut into crescent-shaped sections (B) and young branches (C). Defoliation in the apical part of the crown of a K. grandifoliola tree (D). (Source: Souza, RM). 


\section{ACKNOWLEDGMENTS}

The authors would like to acknowledge Fazenda Florestas da Canastra and the Conselho Nacional de Desenvolvimento Científico e Tecnológico (CNPq), grant number 306738/20180 , for supporting this work.

\section{REFERENCES}

Beattie AJ \& L Hughes, 2003. Ant-plant interactions, pp. 211 235. In: Herrera CM \& O Pellmyr (Eds.). Plant-animal interactions: an evolutionary approach. Oxford, Blackwell Publishing.

Jiménez, NI, IR Fosco, GC Nassar, AF Sánchez-Restrepo, MS Danna \& LA Calcaterra, 2020. Economic injury level and economic threshold as required by Forest Stewardship Council for management of leaf-cutting ants in forest plantations. Agricultural and Forest Entomology, 23: 1-10. DOI: https://doi.org/10.1111/afe.12409

Klein, DR., MM Andrade, JA Derengoski, E Duarte, SM Krefta, AC Silveira \& EJ Brun, 2016. Aspectos gerais e silviculturais de Cordia americana, Aspidosperma polyneuron, Toona ciliata e Khaya spp. Revista de Ciências Agroveterinárias, 15: 155164. DOI: https://doi.org/10.5965/223811711522016155

Lemes, PG, AJV Zanuncio, LS Oliveira, MF Matos, GLD Leite, MA Soares, JC Zanuncio \& SL Assis Júnior, 2019. Hypsipyla grandella (Lepidoptera: Pyralidae) boring Khaya ivorensis (Meliaceae) fruits and seeds in Brazil: first report. Florida Entomologist, 102: 266-269. DOI https://doi.org/10.1653/024.102.0151

Magistrali, IC \& N Anjos, 2011. Avaliação de sauveiros externos em eucaliptais de Minas Gerais. Ciência Florestal, 21: 349354. DOI: https://doi.org/10.5902/198050983239

Matrangolo, CAR, RVO Castro, TMC Della-Lucia, RM DellaLucia, AFN Mendes, JMFN Costa \& HG Leite, 2010. Crescimento de eucalipto sob efeito de desfolhamento artificial. Pesquisa Agropecuária Brasileira, 45: 952-957. DOI: https://doi.org/10.1590/S0100-204X2010000900003

Moreira, A, LC Forti, AP Andrade, MA Boaretto \& J Lopes, 2004. Nest architecture of Atta laevigata (F. Smith, 1858) (Hymenoptera: Formicidae). Studies on Neotropical Fauna and Environment, 39: 109-116. DOI: https://doi.org/10.1080/01650520412331333756

Moura, RS, KR Souza, DS Souza, GM Santana, G.M Oliveira, F Venturoli \& CM Silva-Neto, 2017. Dano em Khaya ivorensis provocado por Trigona spinipes na savana brasileira. Acta Brasiliensis, 1: 40-42. DOI: https://doi.org/10.22571/ Actabra11201715

Ribeiro, A, CSJ Silva, AC Ferraz-Filho \& JRS Scolforo, 2018. Financial and risk analysis of African mahogany plantations in Brazil. Ciência e Agrotecnologia, 42: 148-158. DOI: https://doi.org/10.1590/1413-70542018422026717

Silva, LVB \& HL Vasconcelos, 2011. Plant palatability to leafcutter ants (Atta laevigata) and litter decomposability in a Neotropical woodland savanna. Austral Ecology, 36: 504-510. DOI: https://doi.org/10.1111/j.14429993.2010.02169.x

Solomon, SE, M Bacci-Junior, J Martins-Junior, GG Vinha \& UG Mueller, 2008. Paleodistributions and comparative molecular phylogeography of leafcutter ants (Atta spp.) provide newinsight into the origins of Amazonian Diversity. PLoS ONE, 3: e2738. DOI: https://doi.org/10.1371/journal. pone.0002738

Souza, A, R Zanetti \& N Calegario, 2011. Nível de dano econômico para formigas-cortadeiras em função do índice de produtividade florestal de eucaliptais em uma região de Mata Atlântica. Neotropical Entomology, 40: 483-488. DOI: https://doi.org/10.1590/S1519-566X2011000400012

Vasconcelos, HL \& JM Cherrett, 1996. The effect of wilting on the selection of leaves by leaf-cutting ant Atta laevigata. Entomologia Experimentalis et Applicata, 78: 215-220. DOI: https://doi.org/10.1111/j.1570-7458.1996.tb00784.x

Zanetti, R, CS Abreu, SHP Silveira \& ED Andrade, 2017. First report of Hypsipyla grandella (Lepidoptera: Pyralidae) on African mahogany Khaya ivorensis. Scientia Agricola, 74: 492-494. DOI: https://doi.org/10.1590/1678992X-2016-0362

Zanetti, R, JC Zanuncio, JC Santos, WLP Silva, GT Ribeiro \& PG Lemes, 2014. An overview of integrated management of leaf-cutting ants (Hymenoptera: Formicidae) in Brazilian forest plantations. Forests, 5: 439-454. DOI: https://doi.org/10.3390/f5030439

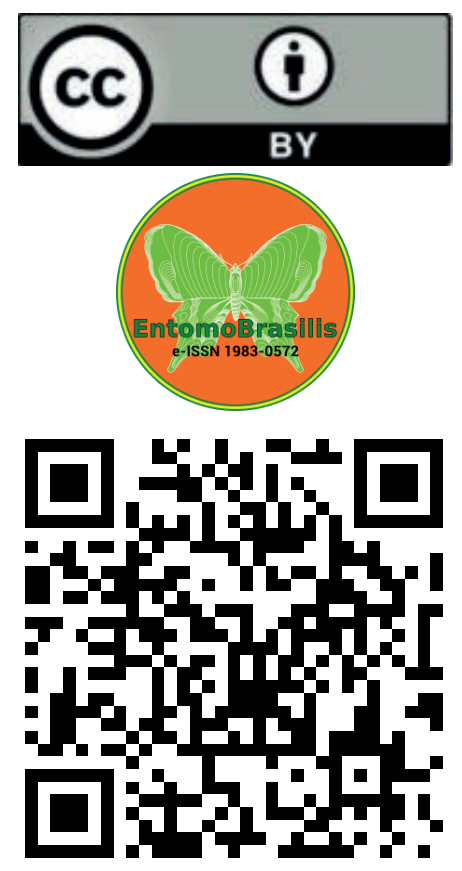

